\title{
PHB Gene
}

National Cancer Institute

\section{Source}

National Cancer Institute. PHB Gene. NCI Thesaurus. Code C20839.

This gene plays a role in the negative regulation of both apoptosis and cell proliferation. 